Reprinted from "The Proceedings of the Indian Academy of Sciences", Vol. XLVI, No. 5, Sec. B, 1957

\title{
THERMAL FIELD AND OCEANIC CIRCULATION ALONG THE EAST COAST OF. INDIA
}

\author{
By A. A. Ramasastry* and C. Balaramamurty \\ (Andhra University, Waltair) \\ Received 20 April, 1957 \\ (Communicated by Dr. N. K. Panikkar, F.A.sc.)
}

\begin{abstract}
From the bathythermographic data, collected during the first 19 cruises of the Andhra University during the period October 1952 to April 1953 along the east coast of India, thermal fields at surface, 40, 100, 200 and 400 feet levels have been constructed for the three seasons, viz., Post-Monsoon, Winter and Summer seasons. The present study is confined to the coastal region between latitudes $13^{\circ} \mathrm{N}$. to $18^{\circ} \mathrm{N}$. and longitudes $80^{\circ} \mathrm{E}$. to $84^{\circ} \mathrm{E}$. In addition to this area, during winter season, the study has been extended to an area over the Swatch of No Ground. From the above, circulation has been deduced and the current directions have been entered on the charts. The limitations and the validity of the method in entering the current directions is discussed and further it is shown, from a consideration of the current boundaries, that the method yields a fairly good representation of the oceanic circulation at various depths. Seasonal variation in the thermal structure and the associated circulation is presented.

In the Post-Monsoon and Hot Weather seasons the current pattern indicates turbulence in the surface layers as a consequence of sinking and upwelling. Greater turbulence occurs off Visakhapatnam than off Madras. At a level at which thermocline forms, currents are opposing to those found above and below that level. A nearly isothermal water mass which forms over the continental shelf during the Hot Weather season appears as a semi-permanent feature, keeping its position due to the existing north-easterly current.
\end{abstract}

\section{INTRODUCTION .}

LAFOND (1954), LaFond and Borreswara Rao (in print) and Ramasastry. (1954) have made extensive studies on the temperatures of the Bay of Bengal and have indicated the possible currents in the Bay. But they have not constructed any charts showing the currents in the Bay. In the present investi-

\footnotetext{
* Present address: Central Marine Fisheries Research Station, Ernakulam. .
} 
gation charts showing the directions of currents at various depths have been presented, each set to represent a particular season.

\section{Treatment of Data}

Numerous bathythermographic data along the east coast of India are available from October 1952 to April 1953, the data having been collected by the Andhra University personnel as a part of the research programme for that year. Part of those observations which lie between latitudes $13^{\circ} \mathrm{N}$. and $18^{\circ} \mathrm{N}$. and longitudes $80^{\circ} \mathrm{E}$. and $84^{\circ} \mathrm{E}$. have been utilised in the present investigation and in addition observations in December 1952 over one more area, the Swatch of No Ground, the submarine canyon, at the mouths of the Ganges and the Brahmaputra, have been utilised. The total period of observations has been divided into three seasons, viz., the 'Retreating South-west Monsoon season' or the 'Post-Monsoon season' (October and November), the 'North east Monsoon season' (December-February) and the 'Hot Weather season' (March-April). The positions of some of the stations falling into each of these seasons are shown as dots in the respective surface charts. For each of these seasons isotherms at $1^{\circ} \mathrm{F}$. intervals at surface, 40, 100, 200 and 400 feet depth levels have been constructed. From the thermal fields so obtained the direction of currents has been entered, bearing in mind the following points.

From the dynamics of ocean currents one derives an important relation between the current and the distribution of mass: "The current, flows in such a direction that the water of low density is on the right-hand side of the current and the water of high density on the left-hand side, " this being the case for the northern hemisphere. But at the surface the variation of temperature depends on many factors such as the incoming solar radiation, the time of the day and the season of the year, the difference between the air temperature and the sea. surface temperature, the amounts of precipitation, condensation and evaporation and on the surface winds, etc. Advective processes in the sea and the atmosphere near the sea suface will result in temperature changes. Hence the thermal fields of the surface or a few feet below the sea surface for any season would be complicated and if one derives currents at the surface, purely from the thermal field, the current pattern would be rather complicated.

Another important factor to be considered while drawing currents is the distribution of salinity, as the density of sea-water depends on salinity as well. Surface salinity in the Bay of Bengal shows a considerable annual variation due to large amounts of dilution from the main rivers, the Ganges, the Brahmaputra, the Godavari and the Krishna. Sewell (1929) has studied 
the distribution of surface salinity in the Bay. The authors in a separate paper have considered the Sigma-t field at the surface for drawing the surface currents wherein certain departures from the pattern obtained by the present method are discussed.

For plotting the currents at the surface and in the mixed layer, the distribution of wind is also important and hence its effect is also considered. Hence on the surface charts of the thermal field and the associated currents, observed winds have been entered in Beaufort scale at some of the stations. Depending upon the duration, intensity and fetch of the wind the depth of the mixed layer will be greatly affected resulting in a rearrangement of mass, especially in stable waters. . In such developments of top homogeneous layers wind currents will be impeded.

Upwelling and sinking along the coast result from the semi-permanent wind systems such as the monsoon winds along the east coast of India. LaFond (1954) has examined upwelling and sinking along this coast from March to May and from September to November associated with the Northeast and South-west monsoons respectively. When upwelling takes place the surface flow will be from regions of low temperature to the regions of high temperature and the sub-surface flow will be in the opposite direction. The reverse will be the case with sinking.

If tongue-like distributions of temperature is found currents can be entered bearing in mind that water of high temperature should be on the right of the current. In such a case the current pattern would be almost along the axis of the tongue. But in general this does not give true picture because of the negligence of the frictional forces and it will be more so at the surface where the temperature depends on many external factors. Sverdrup and Fleming (Oceans, 1946) have found that drift bottle experiments have confirmed the results in a certain case where the flow pattern has been derived on the assumption that the stream lines tend to follow the contour lines of the tongues.

Finally at the coast, currents follow the coast-line. For the subsurface. currents the appropriate contour line acts as the coast-line. Ekman also found that a current will be deflected cum sole while entering shallower water and contra solem while entering deeper water and that these deflections are independent of the absolute depth of the bottom. Considering all these facts current directions are entered on the charts.

3. Discussion of the Thermal Field and the Associated Currents

The Retreating South-west Monsoon Season (October-November).-With the retreat of the South-west Monsoon from India, the centre of low pressure 
has shifted into the centre of the Bay of Bengal and the winds are mainly north-easterly over the region under investigation. With the wind pattern, both at the surface and at 40 feet depth, the currents are mainly directed south-westerly and flow along the coast.

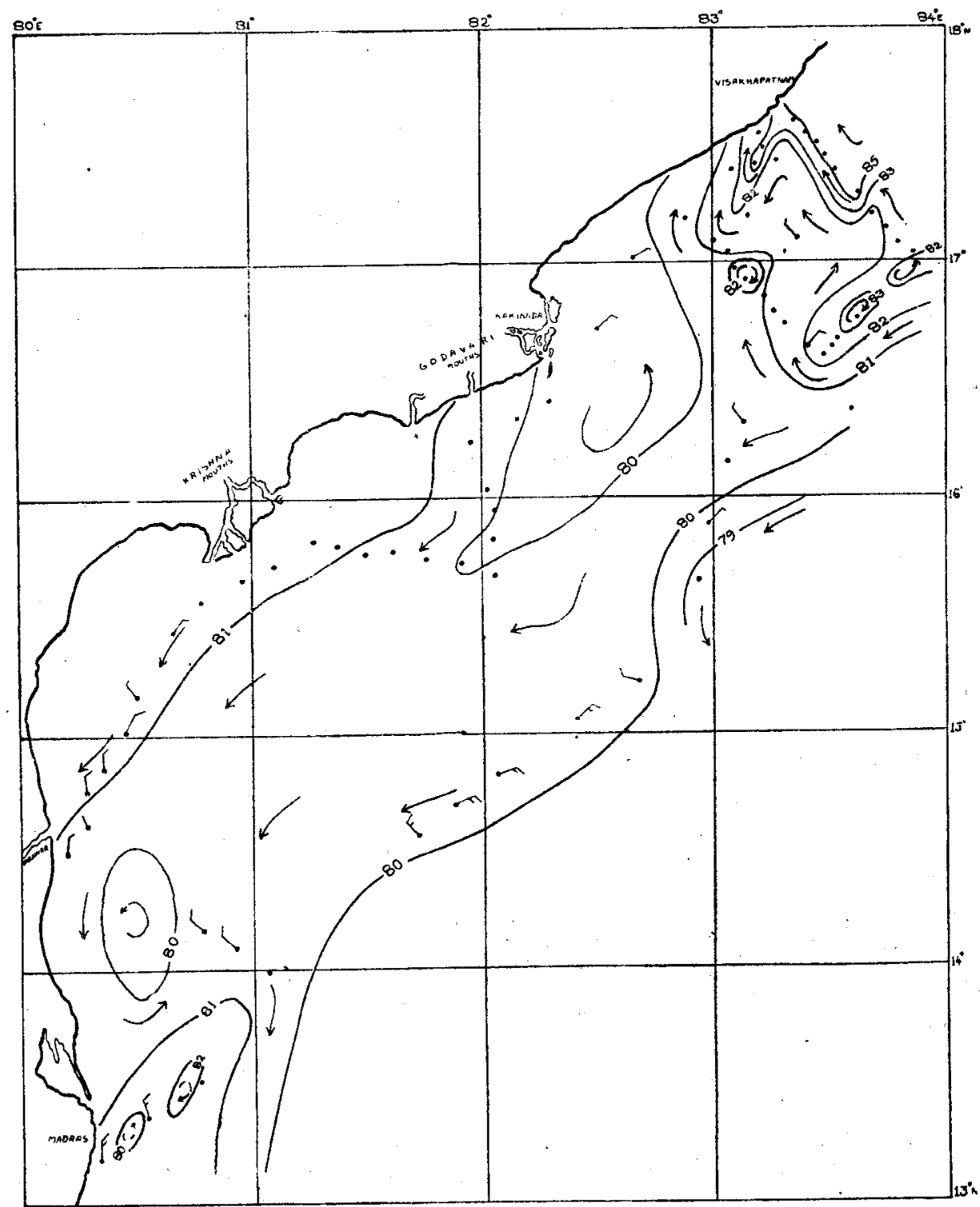

Fig. 1. Thermal field and the associated currents at the sea surface during the Post-Monsoo season along the east coast of India in the region between $13^{\circ} \mathrm{N}$. to $18^{\circ} \mathrm{N}$. and $80^{\circ} \mathrm{E}$. to $84^{\circ} \mathrm{E}$. 
The temperature gradually increases with increasing distance from the coast. Except near the Godavari and the Krishna, south of Vishakapatnam isotherms at both these levels run almost parallel to the coast. A tongue of low temperature is however found off the mouths of the Godavari at the surface (Fig. 1) and also a zone of low temperature off the Pennar. The low temperature zones are characteristic of the river discharges as the run-off from the rivers is generally of lower temperature because of the difference of temperatures between the land and water surfaces. Off Viskahapatnam, however, the isotherms run almost perpendicular to the coast with decreasing temperatures with distance from the coast. Also the temperature decreases towards south. The general trend of low temperatures in the south may partly be attributed to the shift of the rainy season to the Madras coast.

At the surface a coastal current flows towards south below latitude $16^{\circ} \mathrm{N}$. Off the Godavari, due to the tongue of low temperature, a current flows almost in the opposite direction. Due to sinking along this coast in this season the currents should be expected to run from lower temperature to higher temperature side. Such a feature is also clear off the Godavari and off Visakhapatnam. At the latter place a strong current is seen to flow towards the coast at the surface and also at 40 feet depth (Fig. 2). The cellular structure of the complicated pattern of the isotherms and the associated currents off Visakhapatnam, both at the surface and at 40 feet, indicate the amount of turbulence present. The variable winds accompanied by the slow retreat of the monsoon and followed by sinking will generally result in thorough mixing of the upper layers and the formation of eddies.

About 60 miles off Visakhapatnam two rotating currents in opposite directions are noticed at the surface and at 40 feet, while the two merged into one counterclockwise rotation at the 100 feet level showing reduced intensity of turbulence at 100 feet. Only at surface, off Madras, a small zone of high temperature characterised by two opposing currents, purely of thermal origin, are found. These currents (marked in discontinuous arrows) should not be considered too rigidly as the salinity here is high compared to that in the farther north, where much dilution takes place. Considering these two factors the general character of the surface currents should be south-westerly.

Immediately after the run-off from the Godavari at the Sacramento (off Kakinada) in the tongue of low temperature a counterclockwise rotation occurs at the surface while at 40 feet depth it splits up into two oppositely rotating currents, the opposing feature being centered at $16^{\circ} 20^{\prime} \mathrm{N}$. and $82^{\circ} 20^{\prime} \mathrm{E}$. which is completely absent in deeper waters. This might be due 
to the lesser dilution at this place as the fresh-water of the Godavari is taken up northwards by the surface current.

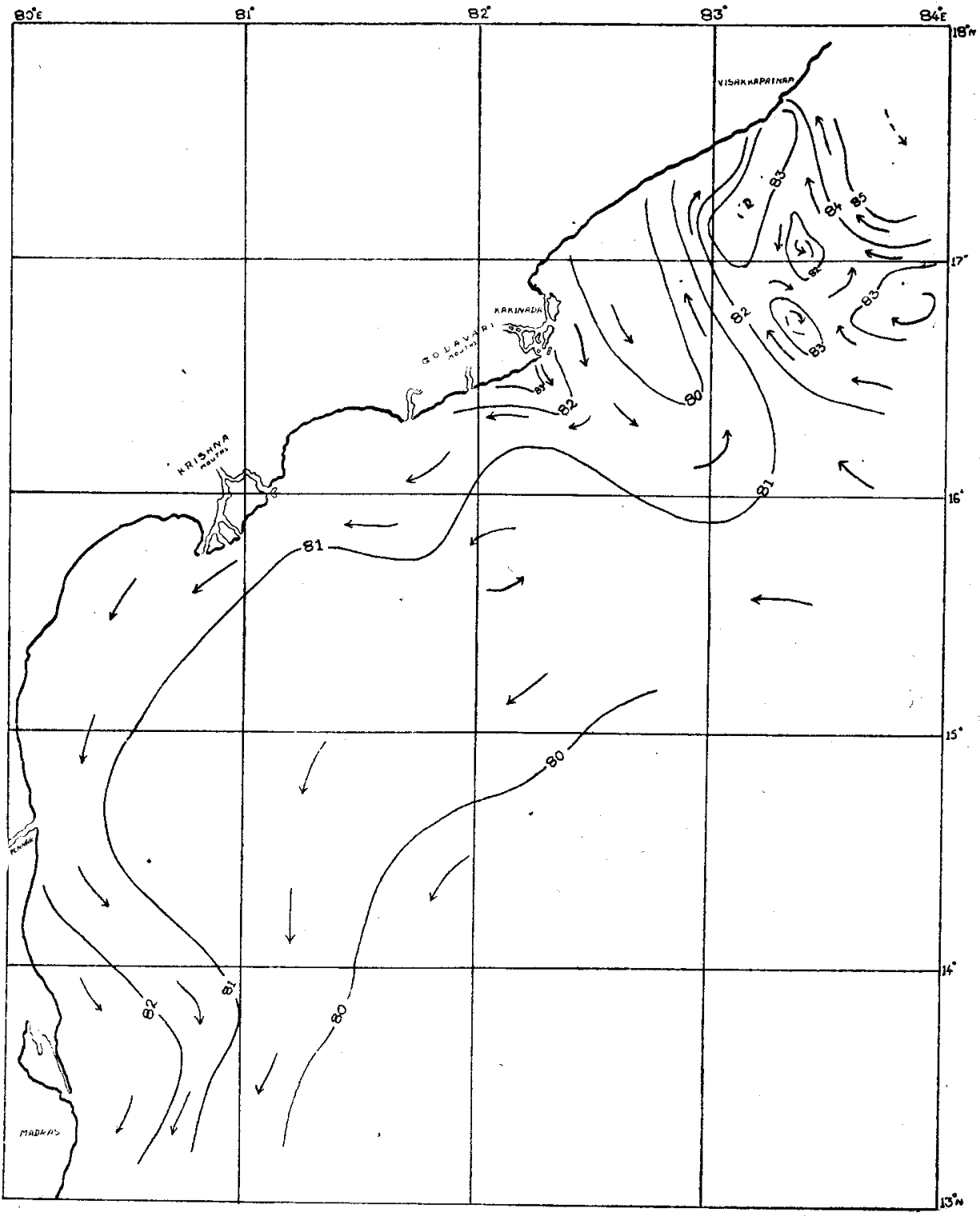

Fig. 2. Thermal field and the associated currents at $40 \mathrm{ft}$. depth level during the Post-Monsoon season along the east coast of India in the region between $13^{\circ} \mathrm{N}$. to $18^{\circ} \mathrm{N}$. and $80^{\circ} \mathrm{E}$. to $84^{\circ} \mathrm{E}$. 
Thermal Field and Oceanic Circulation along East Coast of India 299

At 100 feet (Fig. 3) the temperature field is such that the temperature increases with increasing distance from the shore. As sinking inshore is prominent, at subsurface depths currents should be directed from higher temperatures to the lower temperature side which means a reversal of currents

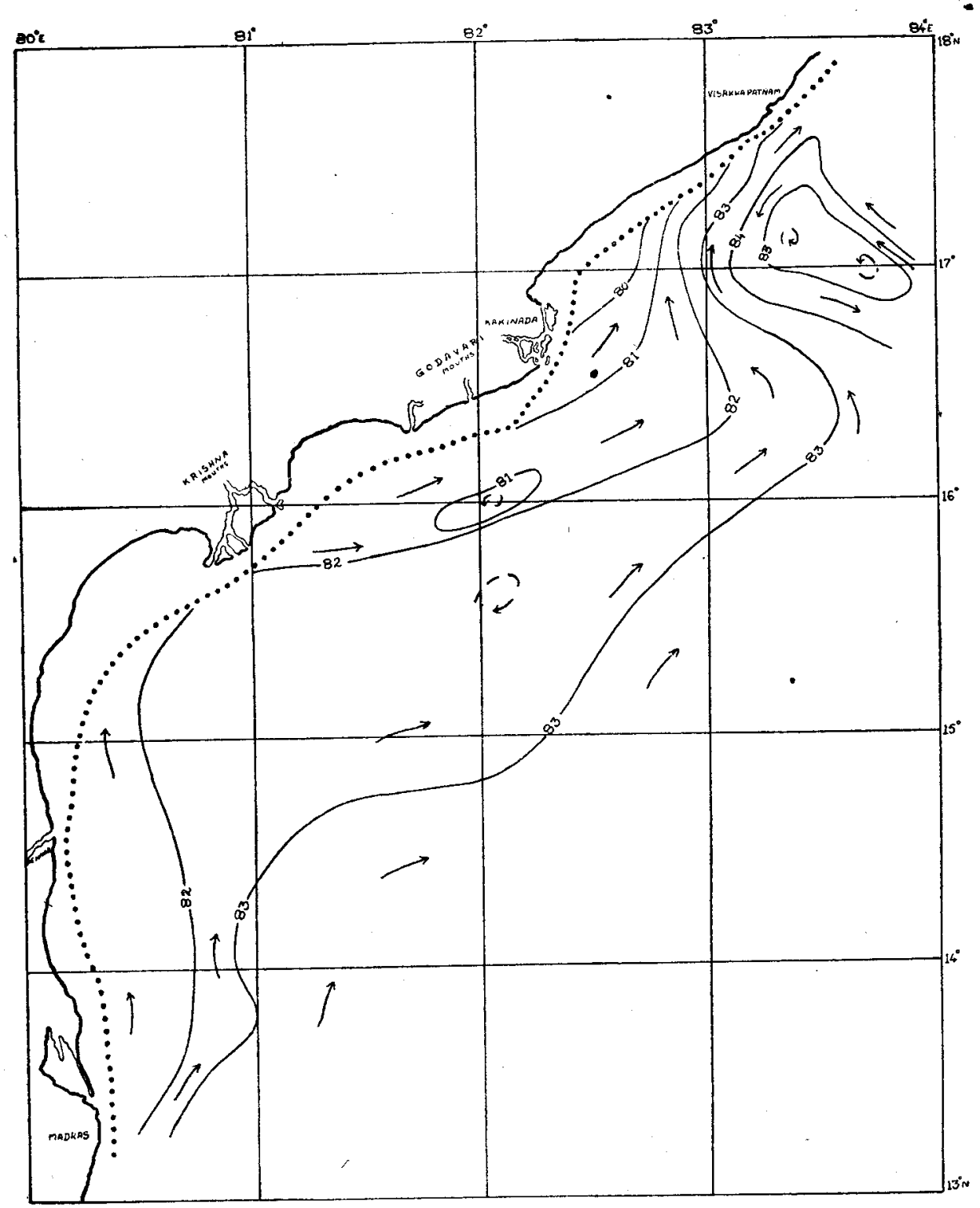

FIG. 3. Thermal field and the associated currents at $100 \mathrm{ft}$. depth level during the PostMonsoon season along the east coast of India in the region between $13^{\circ} \mathrm{N}$. to $18^{\circ} \mathrm{N}$. and $80^{\circ} \mathrm{E}$. to $84^{\circ} \mathrm{E}$. 
as compared to those at the surface and at 40 feet depths. Such a feature is clearly noticed in the circulation along this coast at this depth. The development of thermocline increases in depth as one approaches the shore due to sinking and consequently the temperatures near shore will be lower. Consequently, currents at 100 feet alone are nearly in opposite direction to those above and below this depth. The tongue of low temperature, characteristic of the surface waters off the Godavari, has merged into the trough of low temperature which in general is found at this level along the entire coast. Further, turbulent mixing accompanied by sinking near Madras is almost eliminated. But off Visakhapatnam the eddy formation is still persisting at 100 feet indicating that sinking, even at this level, is more intense than farther
south.

But at 200 feet (Fig. 4) the effects of sinking are completely absent even off Visakhapatnam. Upto 100 feet level the intensity of currents as indicated by the weak temperature field is very low whereas at 200 feet the intensity has increased with increasing intensity in the horizontal temperature gradients. Off the Godavari a subsurface counter current of low intensity is associated. with a tongue-like distribution of higher temperatures in-shore. This, not only shows the continuity of the system at the place but also an increase in vertical stability at this level. The senior author has elsewhere shown that the vertical stability in this region was decreasing in the topmost layers with a depthwise increase thereafter. Except very near the coast the currents are more orderly and towards south-west the small eddy formation off Visakhapatnam, and off the Krishna and the Pennar can be respectively attributed to mixing followed by sinking and to dilution. Partly these may be asso-
ciated with the bottom topography also.

At 400 feet (Fig. 5) level a few isotherms run parallel to the coast and the temperature increases with distance from the coast. The current is somewhat weak and follows the 400 feet line (shown as dotted line along the coast in the figure) in a south-westerly direction. Small deviations from the 400 feet line are associated with the effect of the topography.

Horizontally rotating systems off Visakhapatnam and off the Pennar at 400 feet, and at Madras coast at 200 feet, result due to the effect of the subsurface maximum temperature zone produced by sinking. Towards the middle of this season, due to winter cooling, at the surface; and by the sinking of the surface-waters inshore, the bathythermograms show inversions of temperature at subsurface depths resulting in a zone of maximum temperature round about 200 feet level, which is apt to reduce the vertical stability.
As has been pointed out already, stability decreases in the top layers and shows 
an increase at these depths. This is because of much dilution of the surface waters. However, an increase in stability at these levels impedes vertical

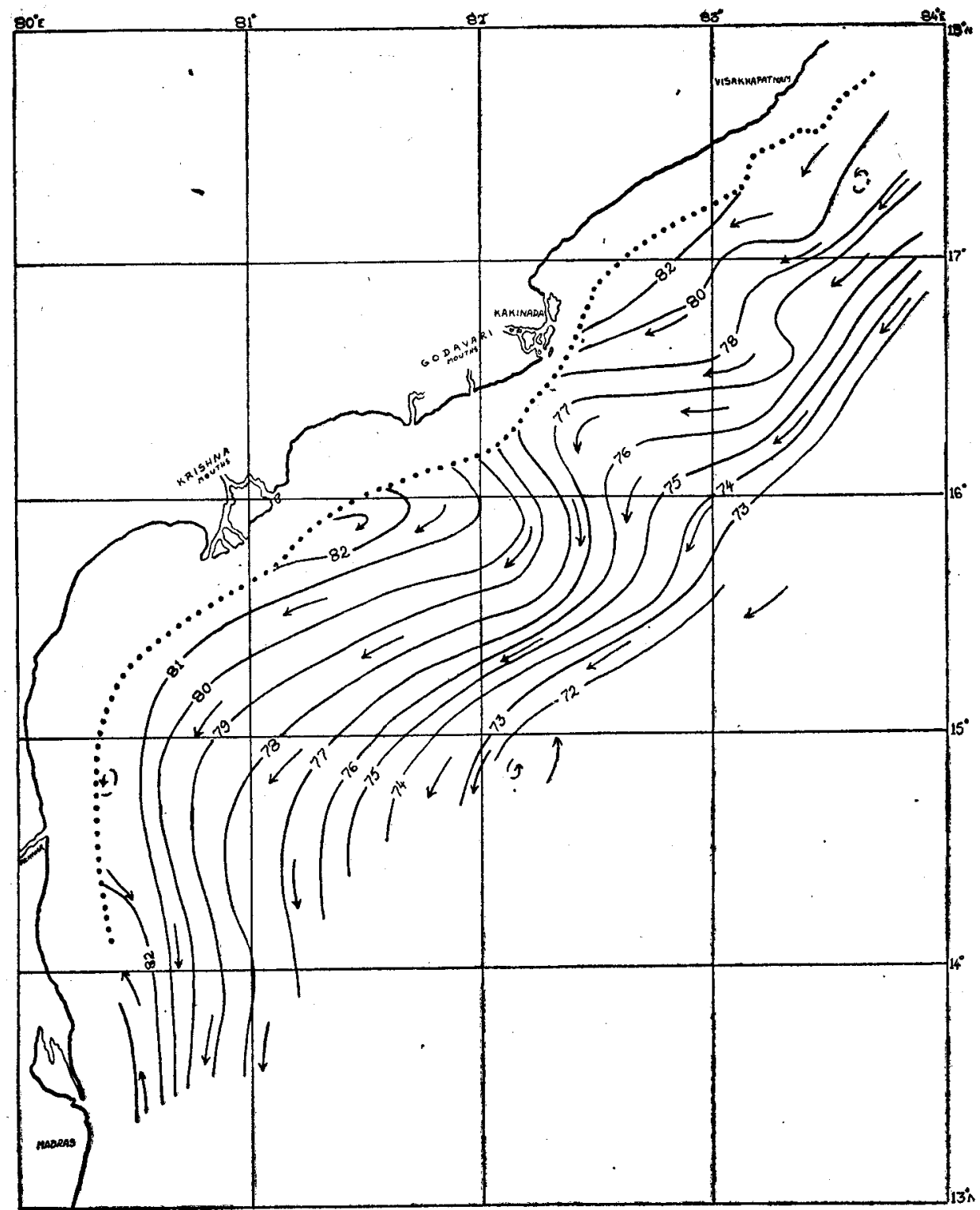

Frg. 4. Thermal field and the associated currents at $200 \mathrm{ft}$. depth level during the PostMonsoon season along the east coast of India in the region between $13^{\circ} \mathrm{N}$. to $18^{\circ} \mathrm{N}$. and $80^{\circ} \mathrm{E}$. to $84^{\circ} \mathrm{E}$. 
movement. Hence as a consequence of the subsurface temperature inversions, in specified regions, clockwise rotations have formed.

The North-east Monsoon Season (December-February).-During this season observations were made north of the Godavari upto the mouths of

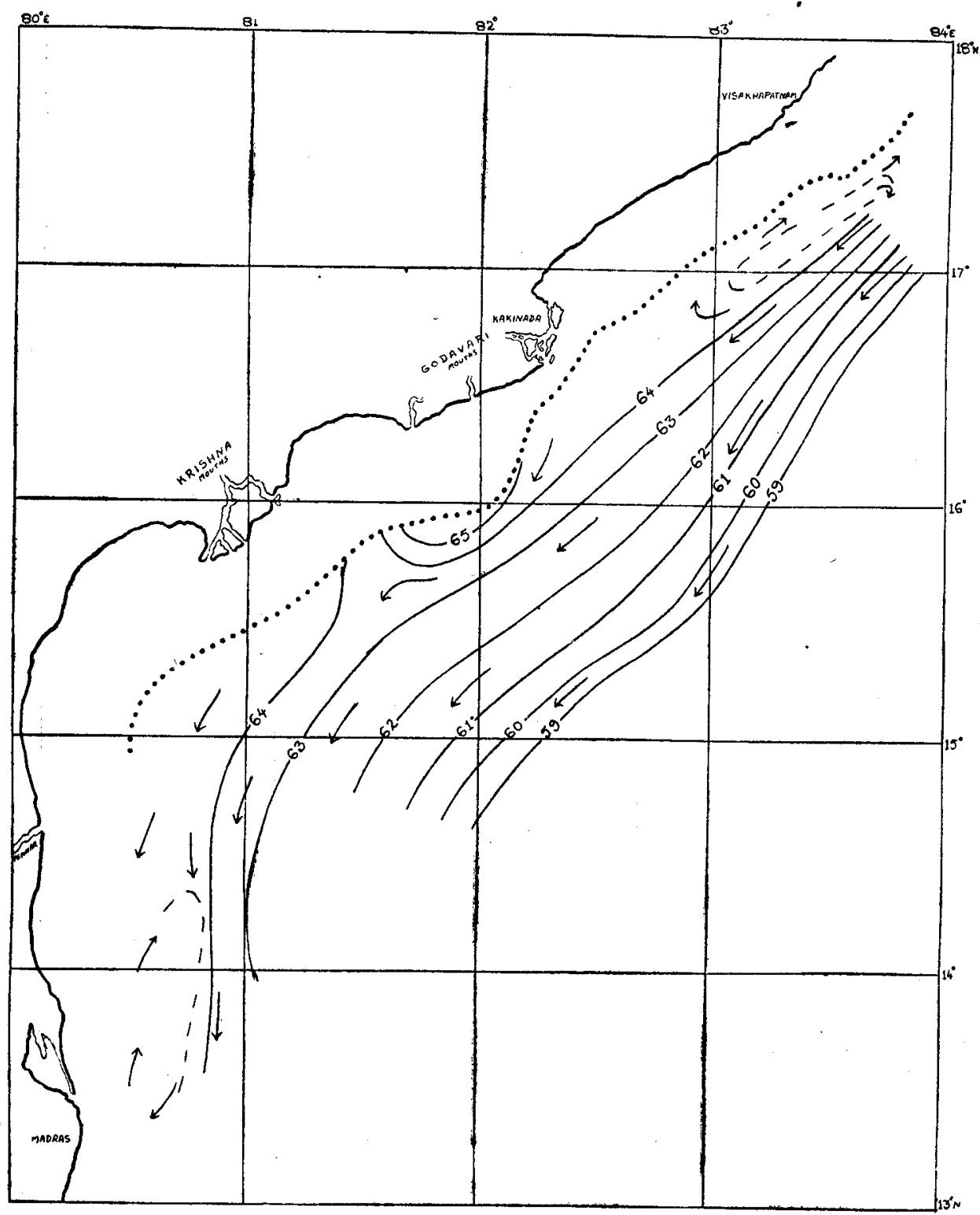

Fig. 5. Thermal field and the associated currents at $400 \mathrm{ft}$. depth level during the PostMonsoon season along the] east coast of India in the region between $31^{\circ} \mathrm{N}$. to $18^{\circ} \mathrm{N}$. and $80^{\circ}$ E. to $84^{\circ} \mathrm{E}$. 
the Ganges. Figures 6-10 and 11-15 represent the thermal field and the associated currents at the coastal region from the Godavari to Visakhapatnam and at the head of the Bay of Bengal respectively.

During this season the surface is cooled by about $2^{\circ} \mathrm{F}$. than in the previous season. Due to the shift of the rainy season to the extreme south of peninsular India and the extreme fair and cold weather conditions all over India the run-off from the rivers is very much reduced in intensity with a consequent rise in salinity of the surface layers. With the increase in salinity and lowering of temperature the density of the upper layers becomes much and vertical convection currents set in. Hence, except early in this season, the subsurface zone of maximum temperature is eliminated (LaFond and Borreswara Rao, 1954; Ramasastry, 1954). The depth of thermocline off Visakhapatnam is greater than that off Kakinada. The depth of the thermocline is greater near the coast than in the offshore waters. Sinking is almost coming to an end early in this season when the phenomenon is confined entirely near the coast. As the season advances sinking reduces in intensity and towards the end the phenomenon is absent. Winds in the region under consideration are very weak and to a certain extent variable in direction early in this season. Owing to all these changes the thermal field at the surface is very complicated (Fig. 6) while at 40 or 100 feet levels it is more orderly. In general temperatures at the surface increase with increasing distance from the shore and the thermal field is poorly defined.

Turbulent mixing of waters, followed by the absence of sinking over the middle of the continental shelf, is confined to the coastal region where two small rotating systems off Visakhapatnam and one off the Sacramento are formed. These are still manifested upto a depth of 200 feet. The main trend of the current in general is towards north-east at the surface (Fig. 6).

At 40 feet (Fig. 7) where the external influencing factors of temperature are less predominant, the clockwise rotation south of Visakhapatnam has gained in dimensions and has formed into a big rotating system. Another such system with still more intensity is found off Visakhapatnam. The two are separated by a small region of low temperatures which at 100 feet level has developed into a tongue of low temperature. Unlike in the previous figure, at 100 feet level (Fig. 8) this tongue of low temperature separates two current systems which are nearly opposing one another. The southerly one is in the anticlockwise direction while the northern system is of variable currents and has a general tendency to rotate in the clockwise direction. The general trend of the offshore current is north-easterly even upto this level. 
A. A. Ramasastry and C. Balaramamurty

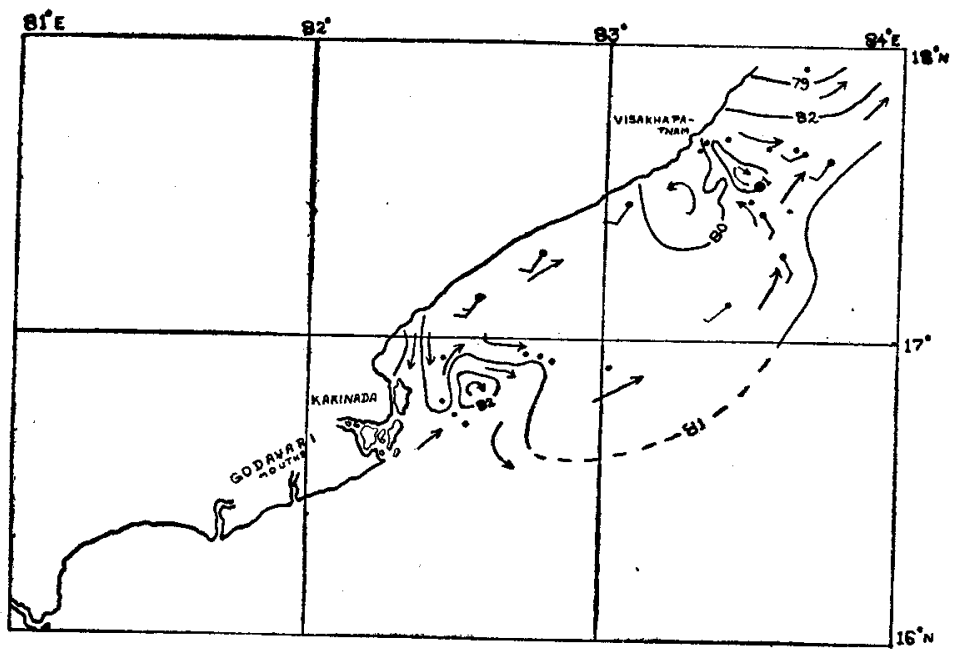

Fig. 6. Thermal field and the associated currents at the sea surface during the North-east Monsoon season along the east coast of India in the region between $16^{\circ} \mathrm{N}$. to $18^{\circ} \mathrm{N}$. and $81^{\circ} \mathrm{E}$. to $84^{\circ} \mathrm{E}$.

The apparent reverse direction at 100 feet level near the Godavari is formed because of the development of thermocline at shallower depths in this region than off Visakhapatnam, where it is formed nearly at 200 feet. This is clearly brought out by an opposing current off Visakhapatnam noticed at 400 feet level. At the transition depth of formation of the thermocline currents are relatively weak and variable in direction. The effect of the res-

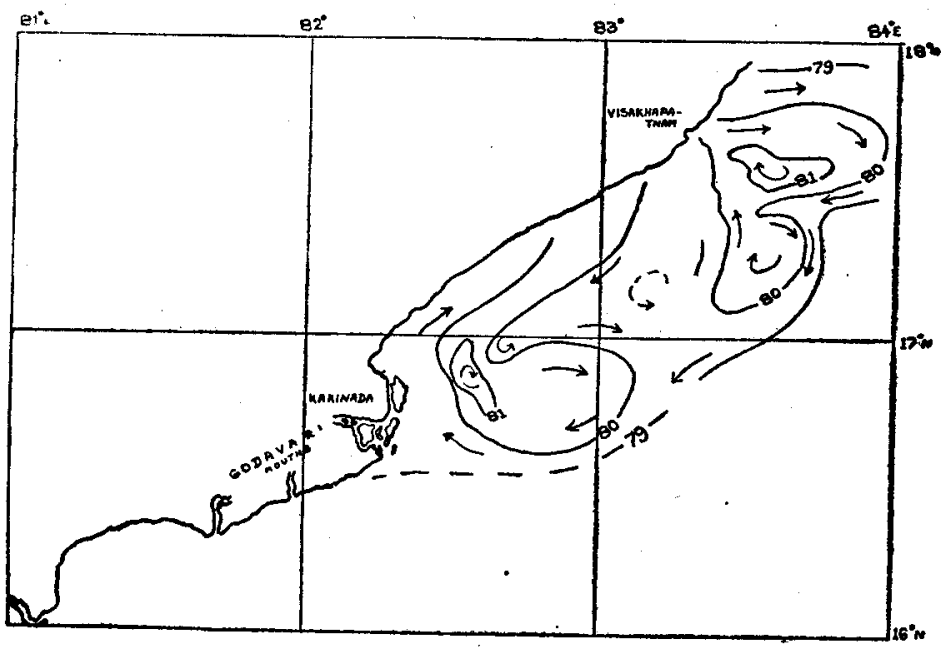

Fig. 7. Thermal field and the associated currents at $40 \mathrm{ft}$. depth level during the North-east Monsoon season along the east coast, of India in the region between $16^{\circ} \mathrm{N}$. to $18^{\circ} \mathrm{N}$. and $81^{\circ} \mathrm{E}$. to $84^{\circ} \mathrm{E}$. 
pective contour lines and the bottom topography at 200 and 400 feet plays an important role in producing deviations in the current directions. This is the transition season between the period of sinking and that of upwelling. Hence while examining the coastal currents one will find a complicated pattern.

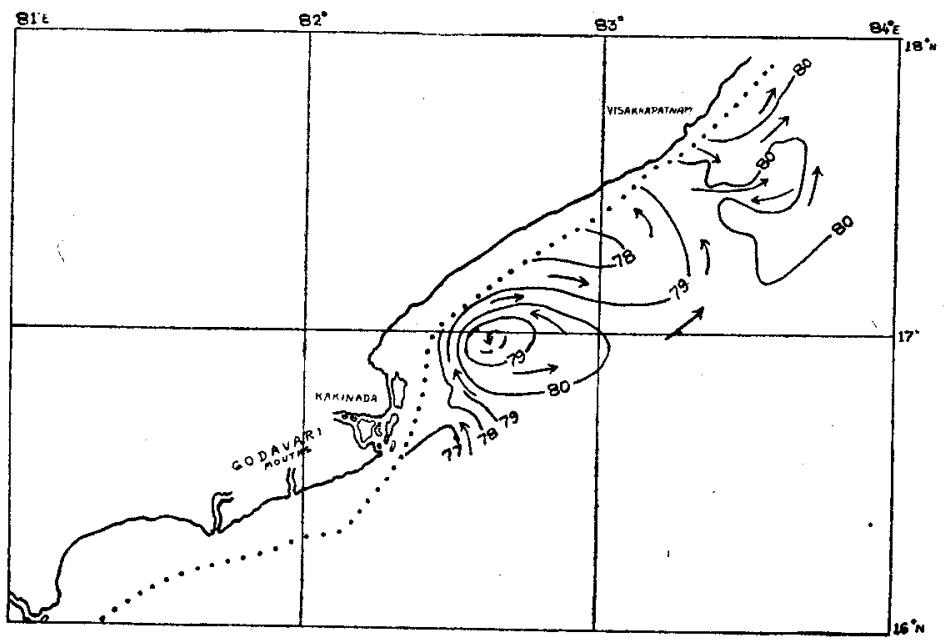

Fig. 8. Thermal field and the associated currents at the $100 \mathrm{ft}$. depth level during the Nortt east Monsoon season along the east coast of India in the region between $16^{\circ} \mathrm{N}$. to $18^{\circ} \mathrm{N}$. an $81^{\circ} \mathrm{E}$. to $84^{\circ} \mathrm{E}$.

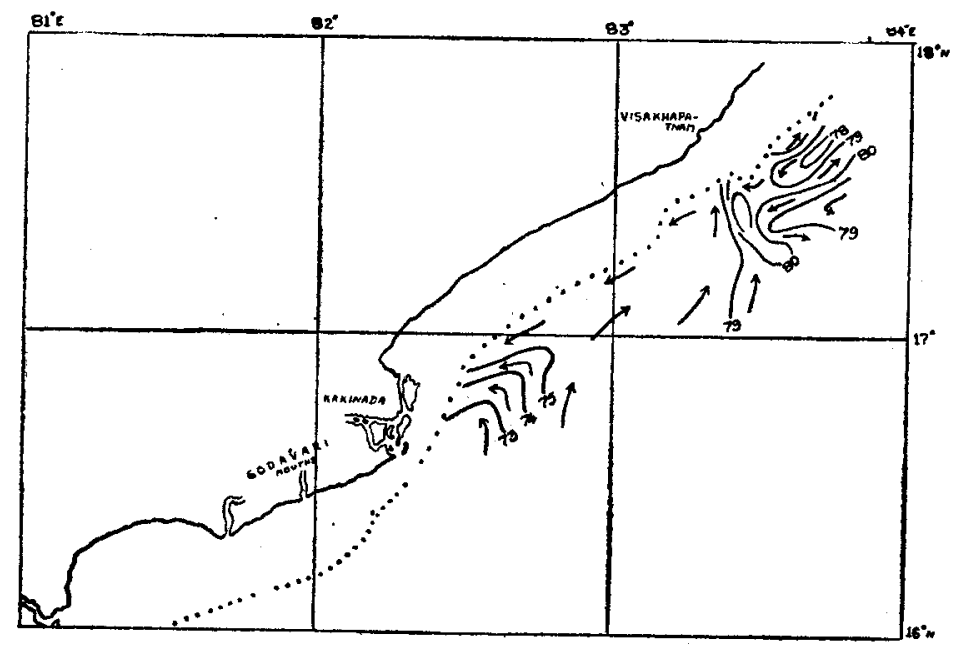

Fig. 9. Thermal field and the associated currents at the $200 \mathrm{ft}$. depth level during the North east Monsoon season along the east coast of India in the region between $16^{\circ} \mathrm{N}$. to $18^{\circ} \mathrm{N}$. and $81^{\circ} \mathrm{E}$. to $84^{\circ} \mathrm{E}$. 
It would be of interest to examine the currents along this coast during this season much more extensively and to a much larger distances from the coast.

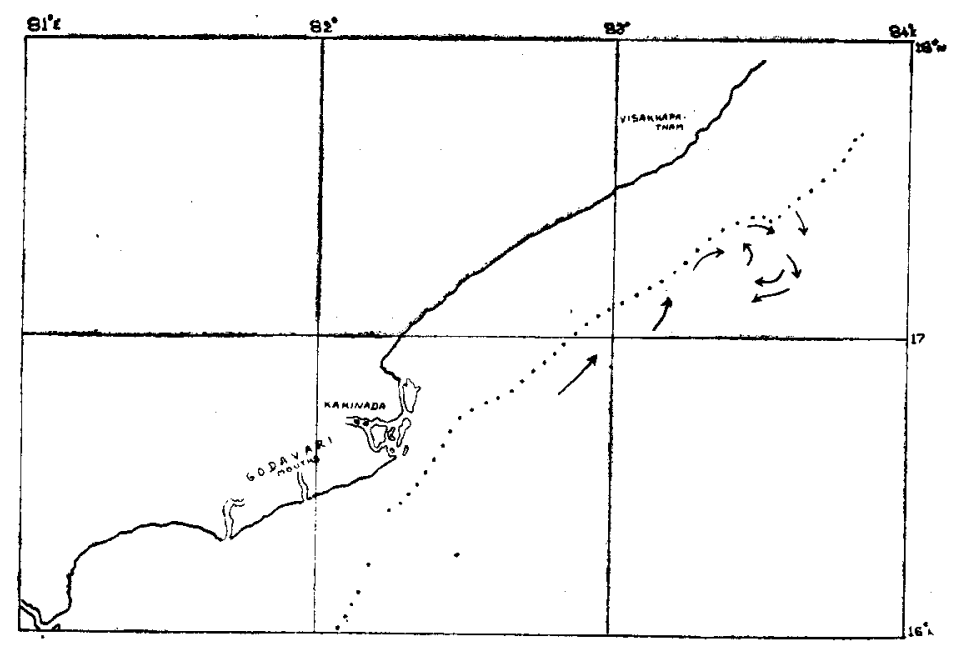

Fig. 10. Thermal field and the associated currents at the $400 \mathrm{ft}$. depth level during the Northeast Monsoon season along the east coast of India in the region between $16^{\circ} \mathrm{N}$. to $18^{\circ} \mathrm{N}$. and $81^{\circ} \mathrm{E}$. to $84^{\circ} \mathrm{E}$.

Currents at the Head of the Bay of Bengal.-The influence of dilution due to the discharges of the Ganges and the Brahmaputra is reflected both in the

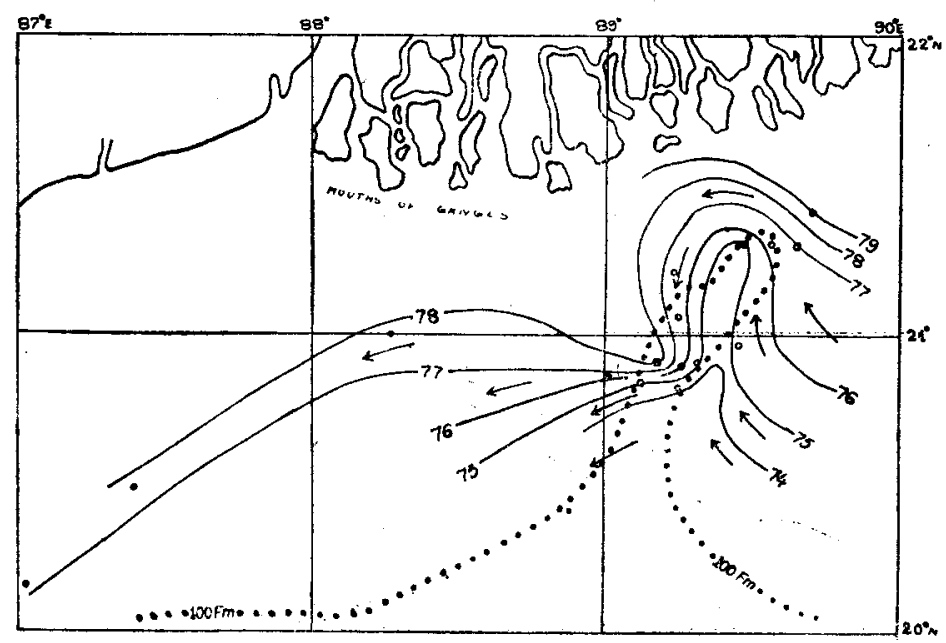

Fig. 11. Thermal field and the associated currents at the sea surface during the North-east Monsoon over the Swatch of No Ground. 
thermal structure and the current pattern at least upto 100 feet level (Figs. 11-13). At the surface (Fig. 11) a tongue of low temperature extends from the south of the canyon (the canyon defined by the $100 \mathrm{fm}$. line, shown in dots in the figure) upto the northern extremity of the canyon. Another tongue of high temperature has formed to the south-west of the canyon. In general, along this coast upto the Mahanadi, temperatures decrease with increasing distance from the coast, whereas an increase in temperature is found off the Visakhapatnam coast. Hence the resulting currents oppose each other at these two localities forming an anticlockwise rotation in a region north of Visakhapatnam and south of the Mahanadi. Such an effect is prominent even upto a depth of 200 feet level (Fig. 14) as is seen by a comparison of the corresponding charts for this season. Due to the two tongue-like formations of temperature at the surface (Fig. 11) an anticlockwise rotation of currents is noticed over the Swatch of No Ground.

At 40 feet level (Fig. 12) the tongue of low temperature is surrounded by isotherms of high temperature. Extreme low temperatures are noticed

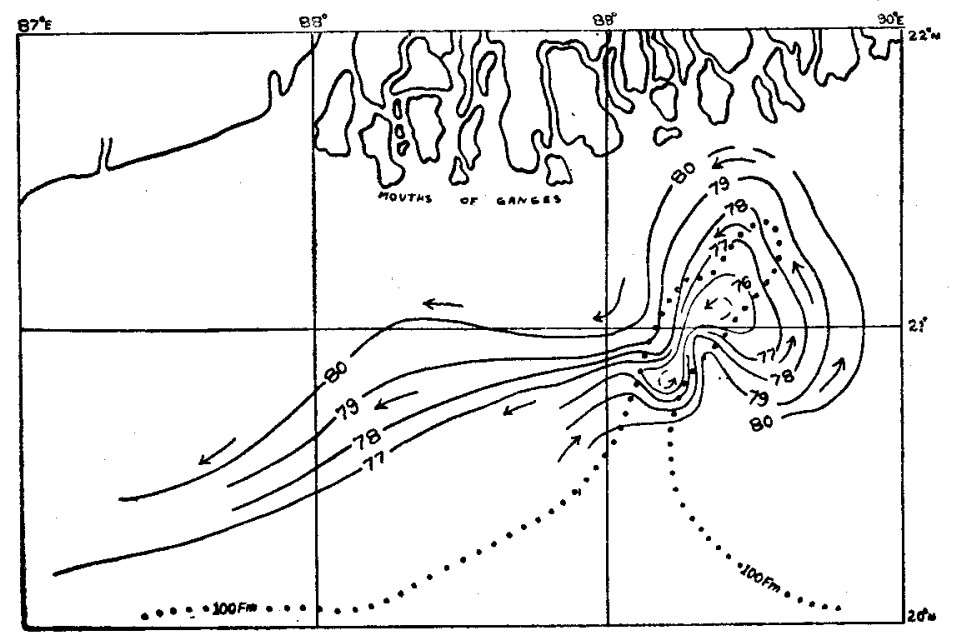

FiG. 12. Thermal field and the associated currents at $40 \mathrm{ft}$. depth level during the North-east Monsoon season over the Swatch of No Ground.

to the south of the canyon. Hence at this level a big clockwise rotation results. A reversal current is not found to any appreciable extent as an effect of the formation of the thermocline. A thermocline in fact did not develop in the top layers and instead a temperature inversion has been noticed upto 200 feet. The rise of temperature between surface and 200 feet is about $5^{\circ} \mathrm{F}$. However over the Swatch of No Groumd the depth of the thermocline is very great. 
At surface and at 40 feet level the currents are mainly relatę to the river discharges while at still lower depths the effect of the bottom topography is felt. The diluted water flows towards the south or south-west where once again good mixing takes place in the eddy formation north of Visakhapatnam coast. Ramasastry (unpublished) studied the vertical stability of the seawater upto $100 \mathrm{~m}$. level in this region and found that the stability in general decreases with depth. At stations which lie exactly on the boundary of the Swatch of No Ground, quite unstable waters are noticed. As a matter of fact, due to higher temperatures near the coast and due to the high dilution one is to expect that the topmost waters to be lighter than those below. If this be the case the vertical stability must increase with increasing depth. But the contradicting observation can only be explained as due to turbulent mixing when the run-off of the rivers mix with the sea-water. This is partly produced by the presence of the submarine canyon. This latter conclusion is justified from the fact that good stability exists off the Godavari or off the Krishna. A recent observation of dilution from the Krishna has further strengthened this view. Photographs taken of the line of demarkation between the river water and the sea-water clearly showed the spread of the river water over the sea surface. Further there is a marked difference in salinity at the boundary surface.

As turbulent mixing at the Swatch of No Ground is not completed, a further clockwise gyrale has to form farther south. The intensity of mixing is much restricted above 100 feet level, as is seen from the close pack of the

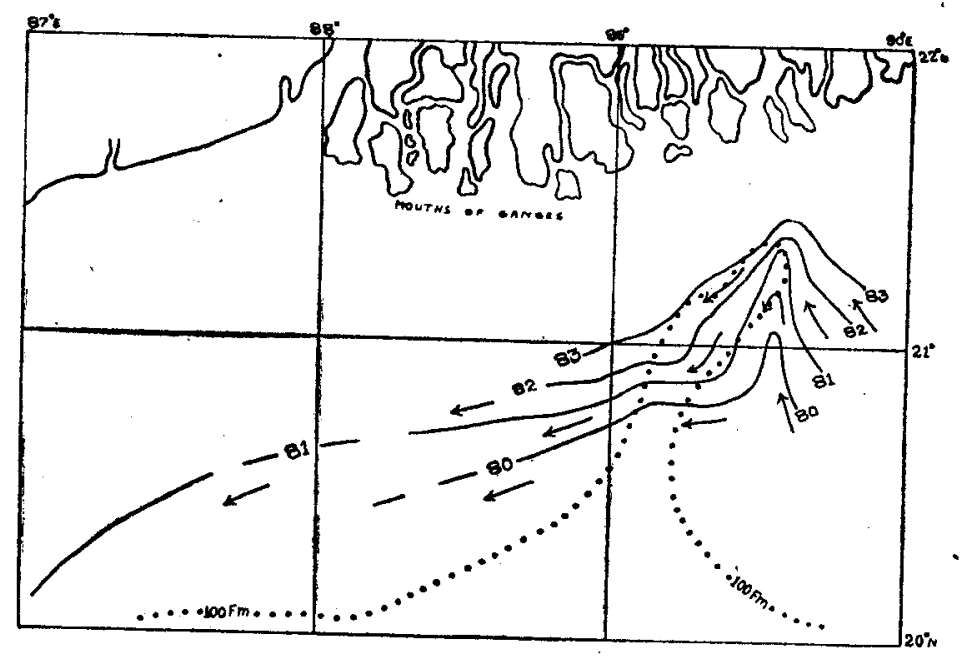

Fig. 13. Thermal field and the associated currents at $100 \mathrm{ft}$. depth level during the North-east Monsoon season over the Swatch of No Ground. 
isotherms. At 100 feet level the spacing between the isotherms has increased, but a tongue of low temperature is extending over the Swatch of No Ground from the south. As a consequence of this a north-westerly current from the Burma coast has turned along this coast to form a south coastal current along the Indian coast.

At 200 and 400 feet levels (Figs. 14 and 15) the observations are relatively poor. At both these levels a current enters into the canyon and gets itself

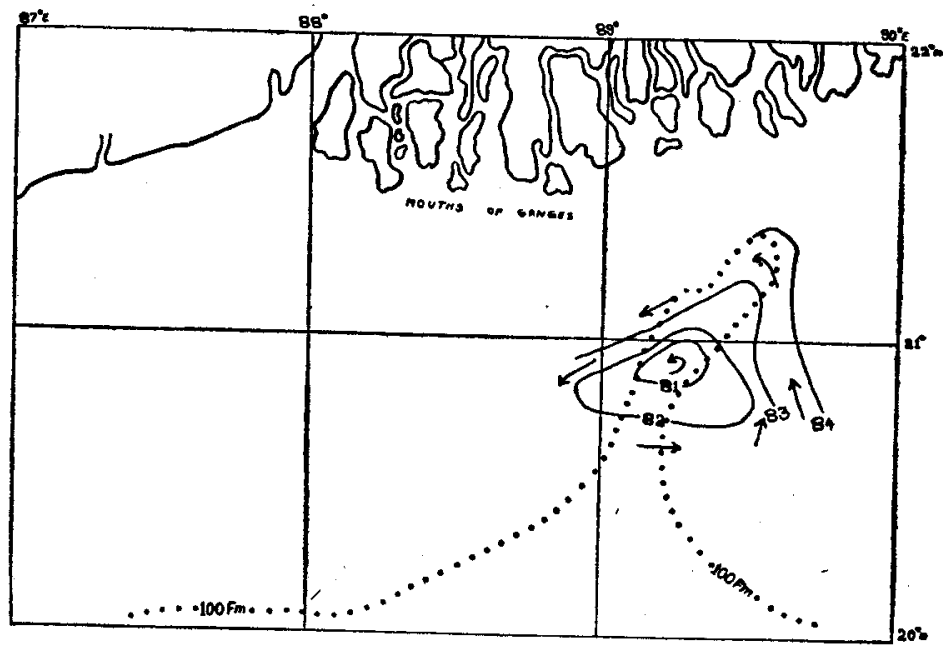

Frg. 14. Thermal field and the associated currents at $200 \mathrm{ft}$. depth level during the Northeast Monsoon season over the Swatch of No Ground.

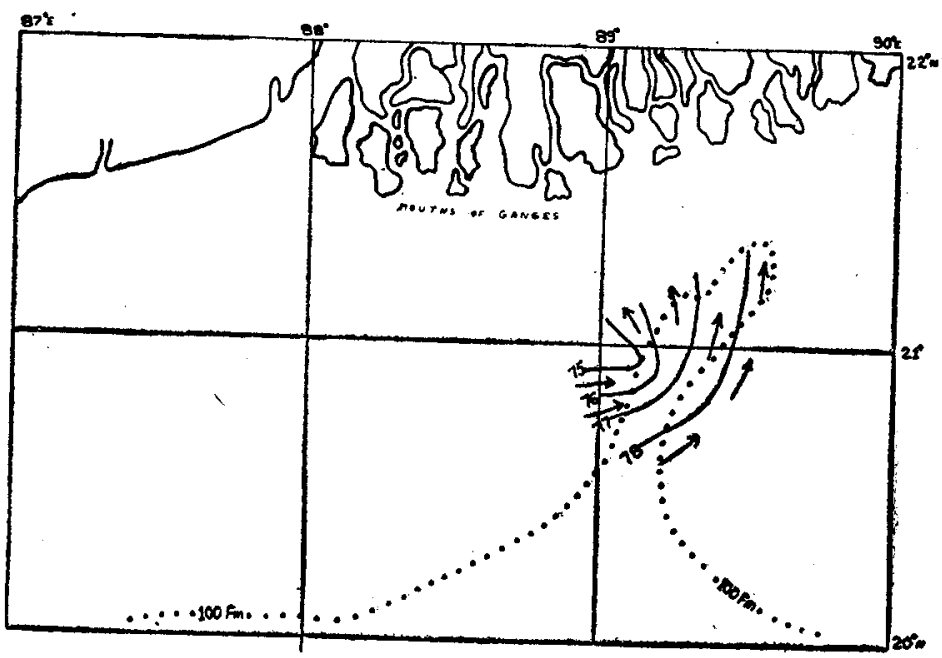

FiG. 15. Thermal field and the associated currer.ts at $400 \mathrm{ft}$. depth level during the North. east Monsoon season over the Swatch of No Ground. 
reflected and turns southwards. As a consequence of the formation of the thermocline below 300 feet a tongue of low temperature replaces the tongue of high temperature found in the surface chart. This results in currents in the opposite directions at this level.

The Hot Weather Season (March and April).-This season is characterised by intense heating and by comparatively weak winds of variable direction and towards the end of the season winds gain in strength and become more south-westerly as the monsoon begins to break from the southern parts of peninsular India. Due to north-easterly winds in the previous season surface water is carried away from the coast as a consequence of which subsurface water rises resulting in upwelling which gains intensity by the middle of this season. In a narrow zone over the continental shelf near the coast the upwelling is more intense resulting in low temperatures. Ramasastry (1954) has found that upwelling during April is more intense off Visakhapatnam than off Madras.

Off Visakhapatnam, at the surface (Fig. 16), the temperature near coast is $81^{\circ} \mathrm{F}$. while over the continental shelf a region of high temperature is found. Here the isotherms are almost perpendicular to the coast. Further into the sea temperatures decrease from the zone of maximum temperature $\left(84^{\circ} \mathrm{F}\right.$. to $81^{\circ}$ F.). Similar features are noticed off the Godavari at 40 feet level (Fig. 17) while at the surface a low temperature zone is surrounded by isotherms - of higher temperature $\left(84^{\circ} \mathrm{F}\right.$.). The temperature in both the cases decreases towards east. But conditions off Madras are slightly different. There is a gradual increase in temperature (from about $80-82^{\circ} \mathrm{F}$.) with increasing distance from the coast. The thermal structure at surface and 400 feet levels along the coast, from Visakhapatnam to the Godavari, is somewhat complicated and the associated currents generally show eddy formations. This is a consequence of turbulent mixing followed by upwelling.

At the surface and 40 feet levels the current pattern, very near the shore, exhibit a clockwise rotation off Visakhapatnam and north of the Godavari, and a counterclockwise rotation off south of the Godavari. The latter is due to the mixing of the Godavari waters. Well off into the sea the main current in this season is north-easterly. This is in conformity with Sewell's findings of the surface currents in this season which show a northerly current south of the Peninsula as entering the Bay and taking a turn following the coast towards north-east and forming two clockwise gyrales centered at $15^{\circ} \mathrm{N}$. and $90^{\circ} \mathrm{E}$. Eddy formation still persists even upto a depth of 200 feet.

At 100 and 200 feet levels (Figs. 18 and 19) off Visakhapatnam the coastal currents are nearly opposing one another showing that upwelling continues 
from a depth of 100 feet level while at 200 feet level the intensity is further reduced resulting even in a counter-flow. Upto a depth of 400 feet the East Indian Coastal Current is north-easterly and temperature increases with distance away from the coast. The reason for a belt of low temperature

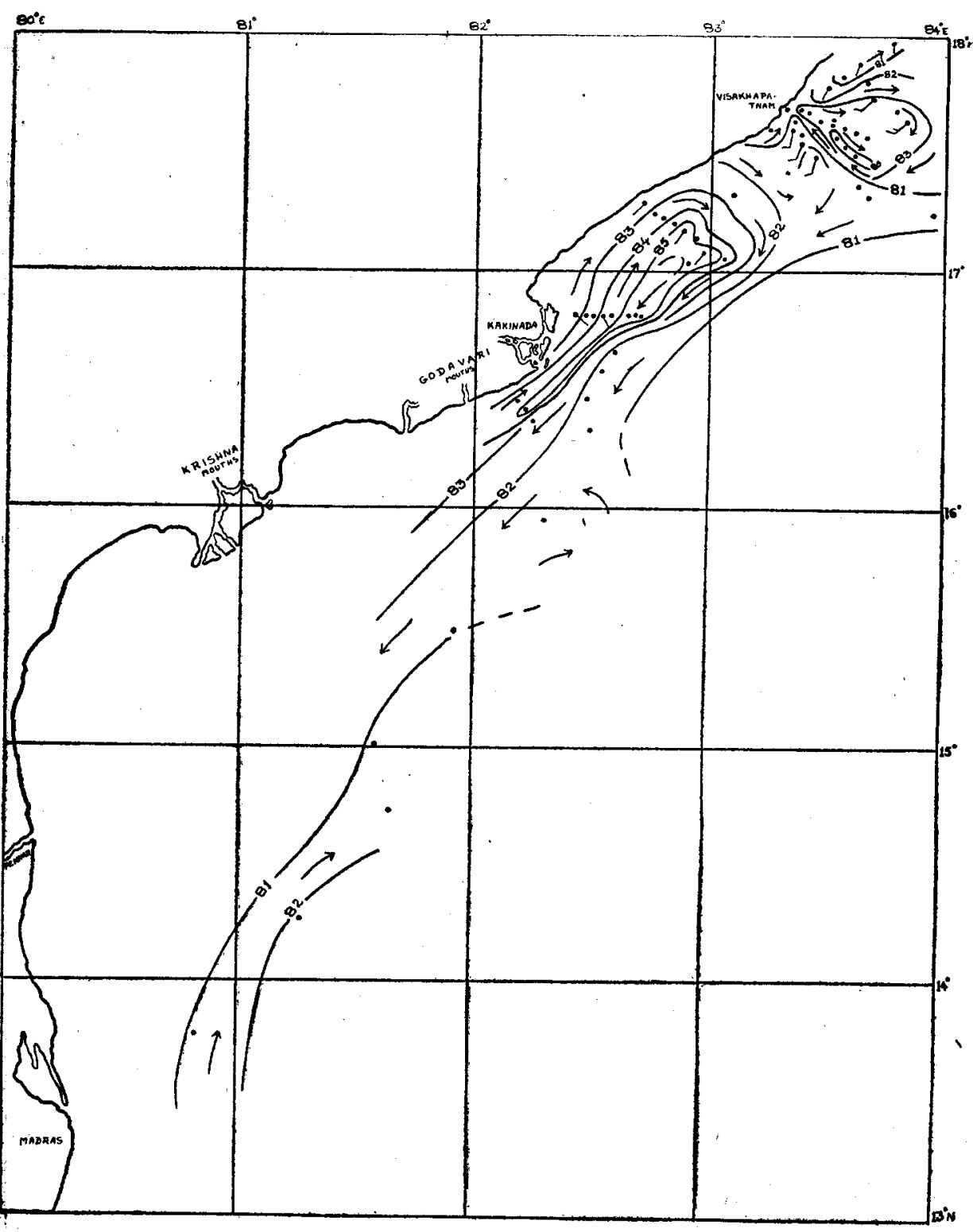

Fug. 16. Thermal field and the associated currents at the sea surface during the Hot Weather season along the east coast of India in the region between $13^{\circ} \mathrm{N}$. to $18^{\circ} \mathrm{N}$. and $80^{\circ} \mathrm{E}$. to $84^{\circ} \mathrm{E}$. 
along the coast is the formation of the thermocline in the topmost layers of the sea as a consequence of upwelling.

While discussing the formation of a bottom watermass over the continental shelf characterised by zero gradients of temperature in the vertical,

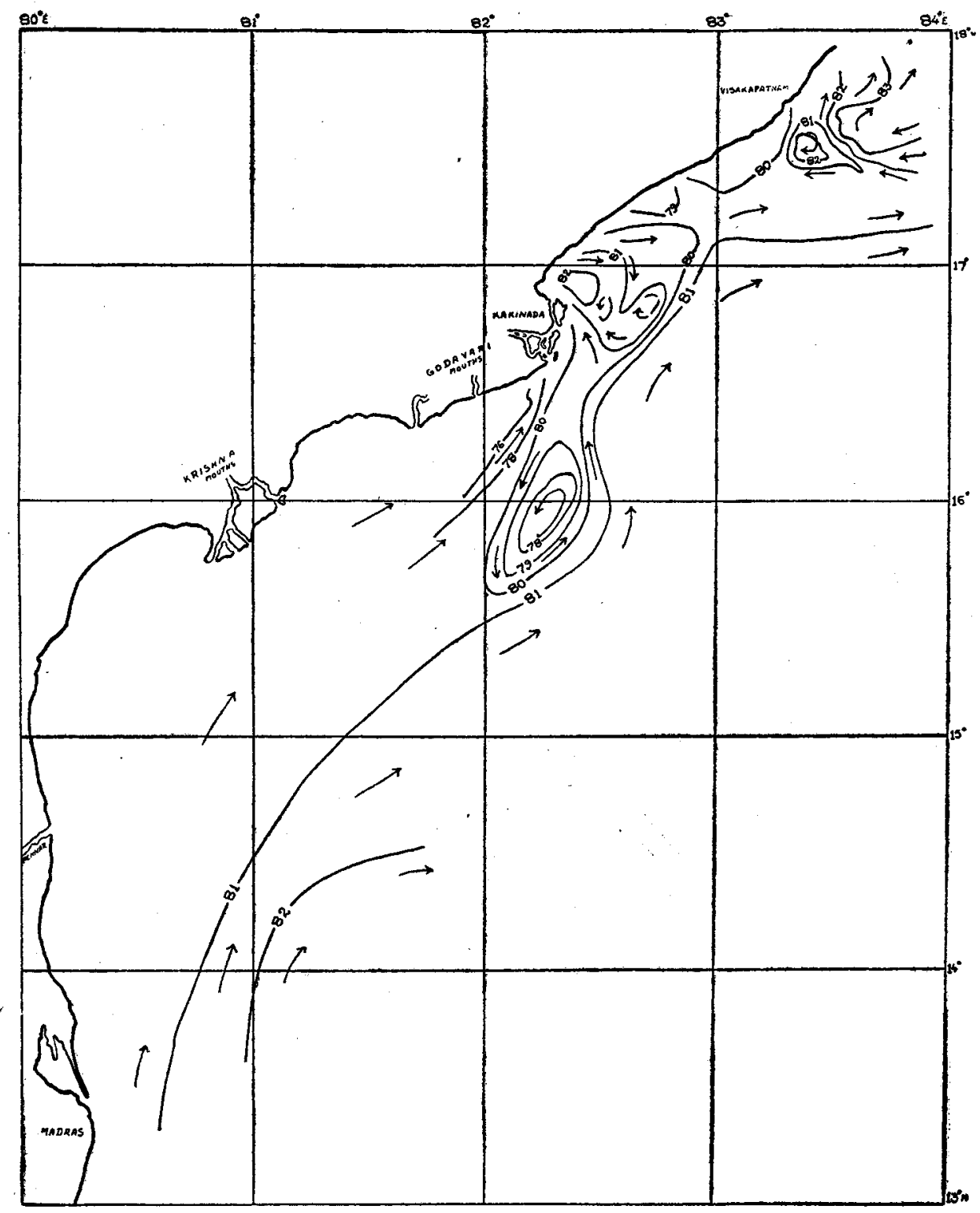

FIG. 17. Thermal field and the associated currents at $40 \mathrm{ft}$. depth level during the Hot Weathe season along the east coast of India in the region between $13^{\circ} \mathrm{N}$. to $18^{\circ}$. N. and $80^{\circ} \mathrm{E}$. to $84^{\circ} \mathrm{E}$. 
Ramasastry (unpublished) has indicated the possibility of turbulent and lateral mixing along this coast. Such features are confirmed by the present study off Visakhapatnam where large eddies are seen even upto a depth of 400 feet. Also it has been found that off the Godavari there exists this type of water

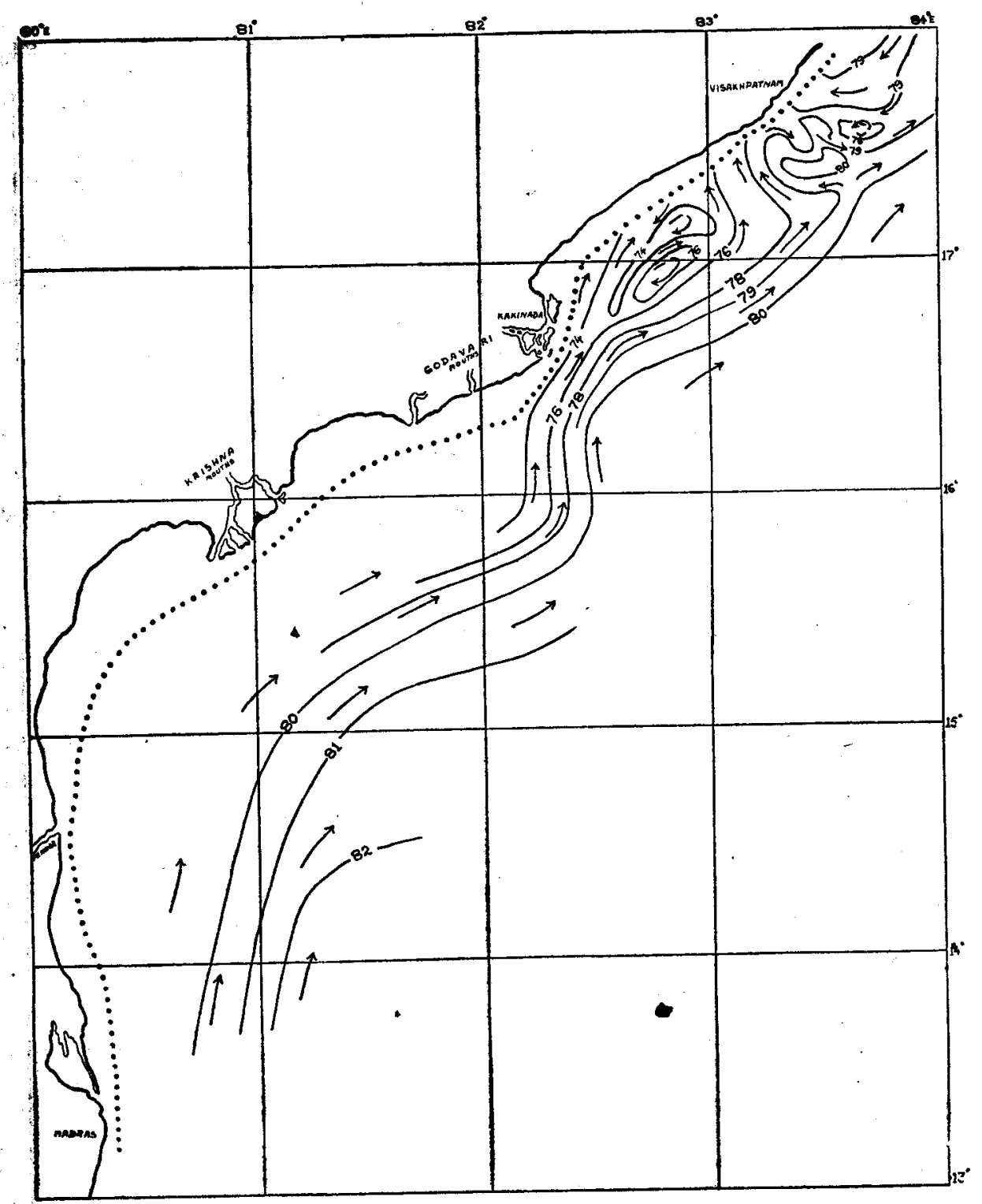

FIG. 18. Thermal field and the associated currents at $100 \mathrm{ft}_{\text {; }}$ depth level during the Hot Weather season along the east coast of India in the region between $13^{\circ} \mathrm{N}$. to $18^{\circ} \mathrm{N}$. and $80^{\circ} \mathrm{E}$. to $84^{\circ} \mathrm{E}$. 
over the continental shelf. The bent of the East Indian Coastal Current towards east and north-east at 400 and 200 feet levels respectively keeps the position of the present watermass on the continental shelf for a fairly long period in this season. With the weakening of upwelling and the onset of

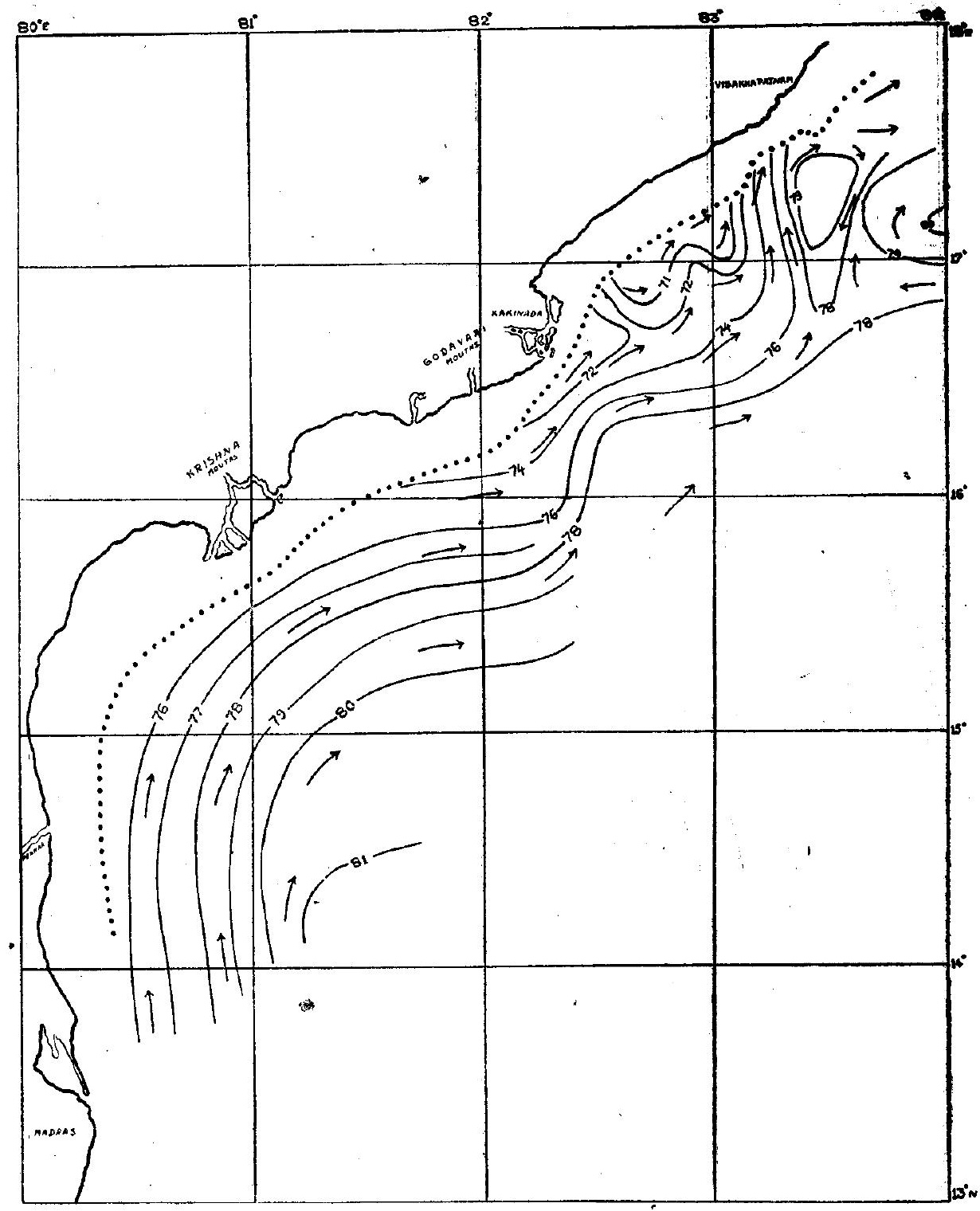

FIG. 19. Thermal field and the associated currents at $200 \mathrm{ft}$. depth level during the Ho Weather season along the east coast of India in the region between $13^{\circ} \mathrm{N}$. to $18^{\circ} \mathrm{N}$. and $80^{\circ} \mathrm{E}$. 84..$^{\circ}$. 
monsoon, this feature gradually disappears. Further the water over the continental shelf is carried north-east by the North Equatorial Current of the Indian Ocean which forms a north-easterly flowing coastal current along this

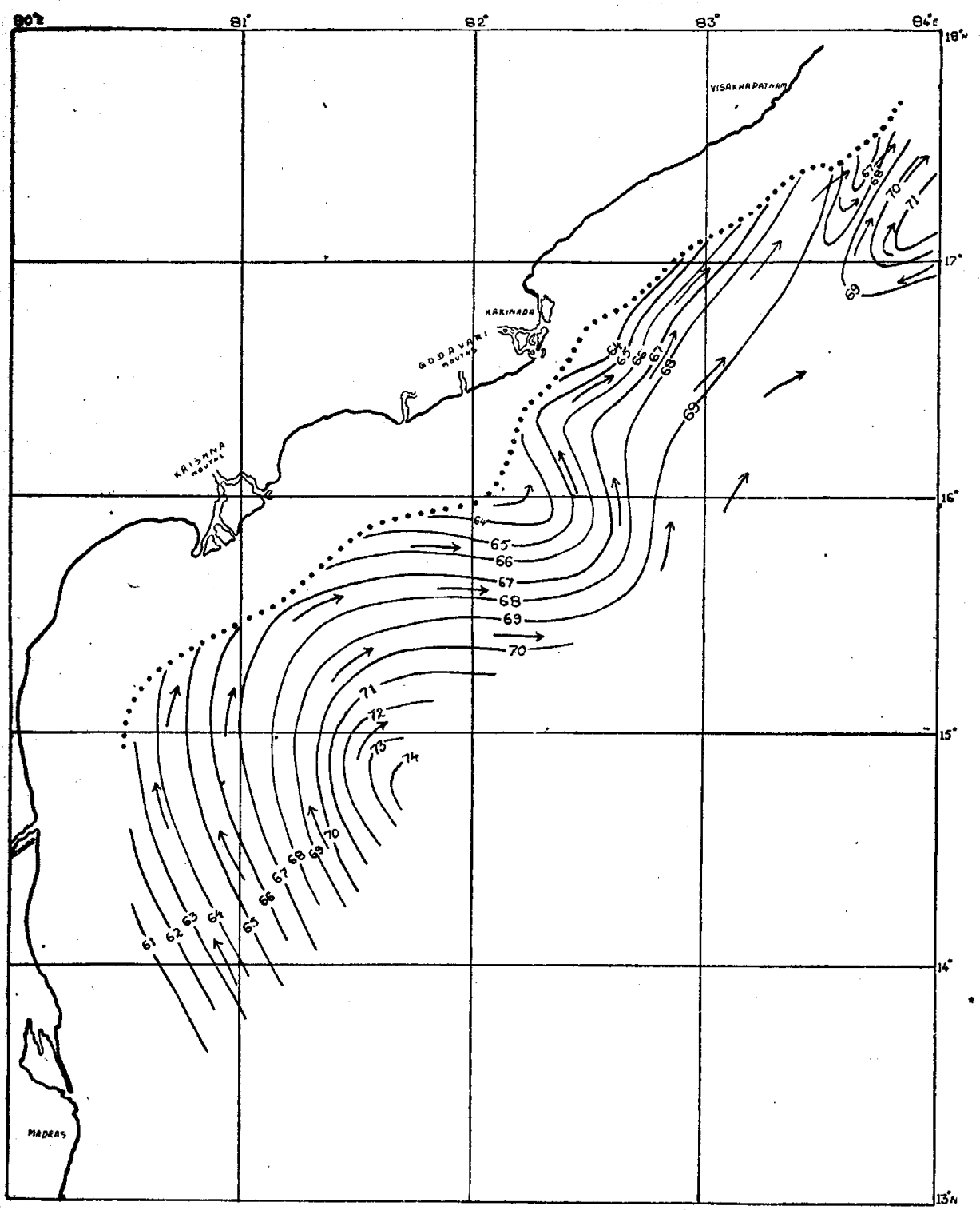

FiG. 20. Thermal field and the associated currents at $400 \mathrm{ft}$. depth level during the Hot Weather season along the east coast of India in the region between $13^{\circ} \mathrm{N}$. to $18^{\circ} \mathrm{N}$. and $80^{\circ} \mathrm{E}$. to $84^{\circ} \mathrm{E}$. 
TABLE I

Analysis of bathythermograms at regions of current boundaries

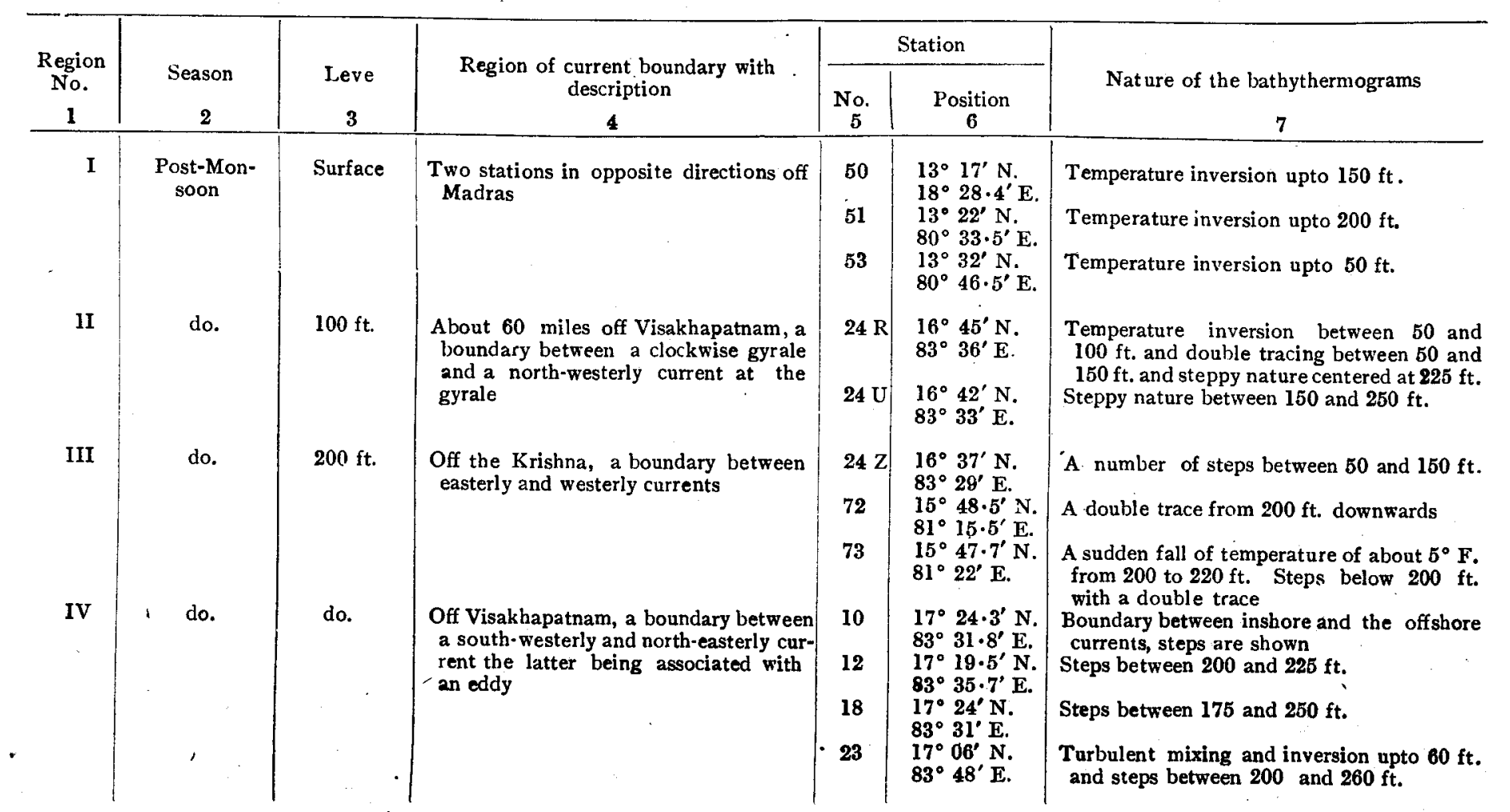

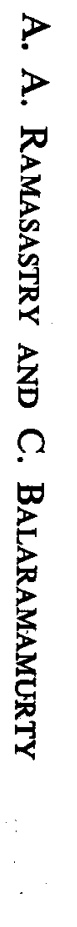




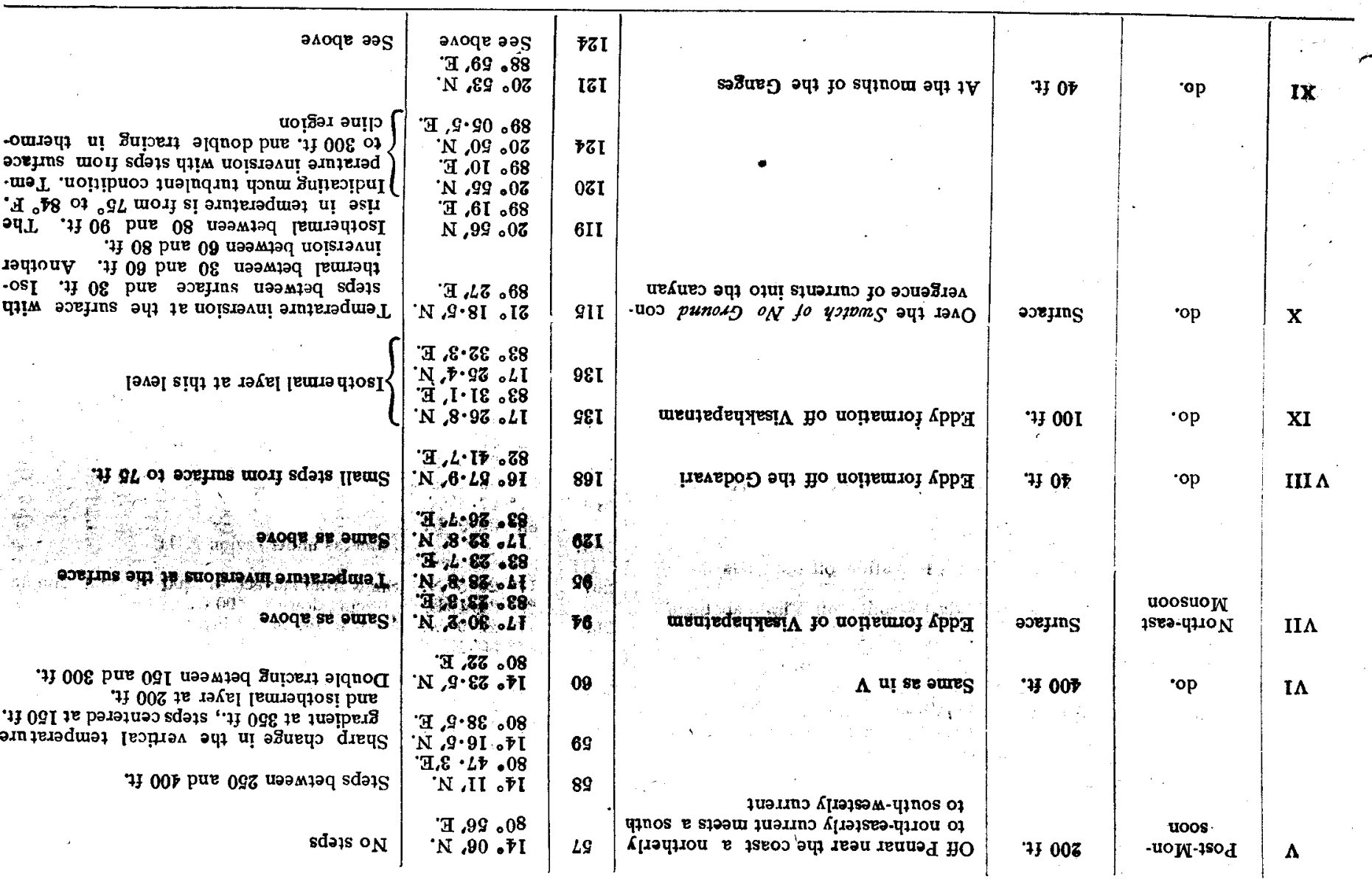


TABLE I (Contd.)

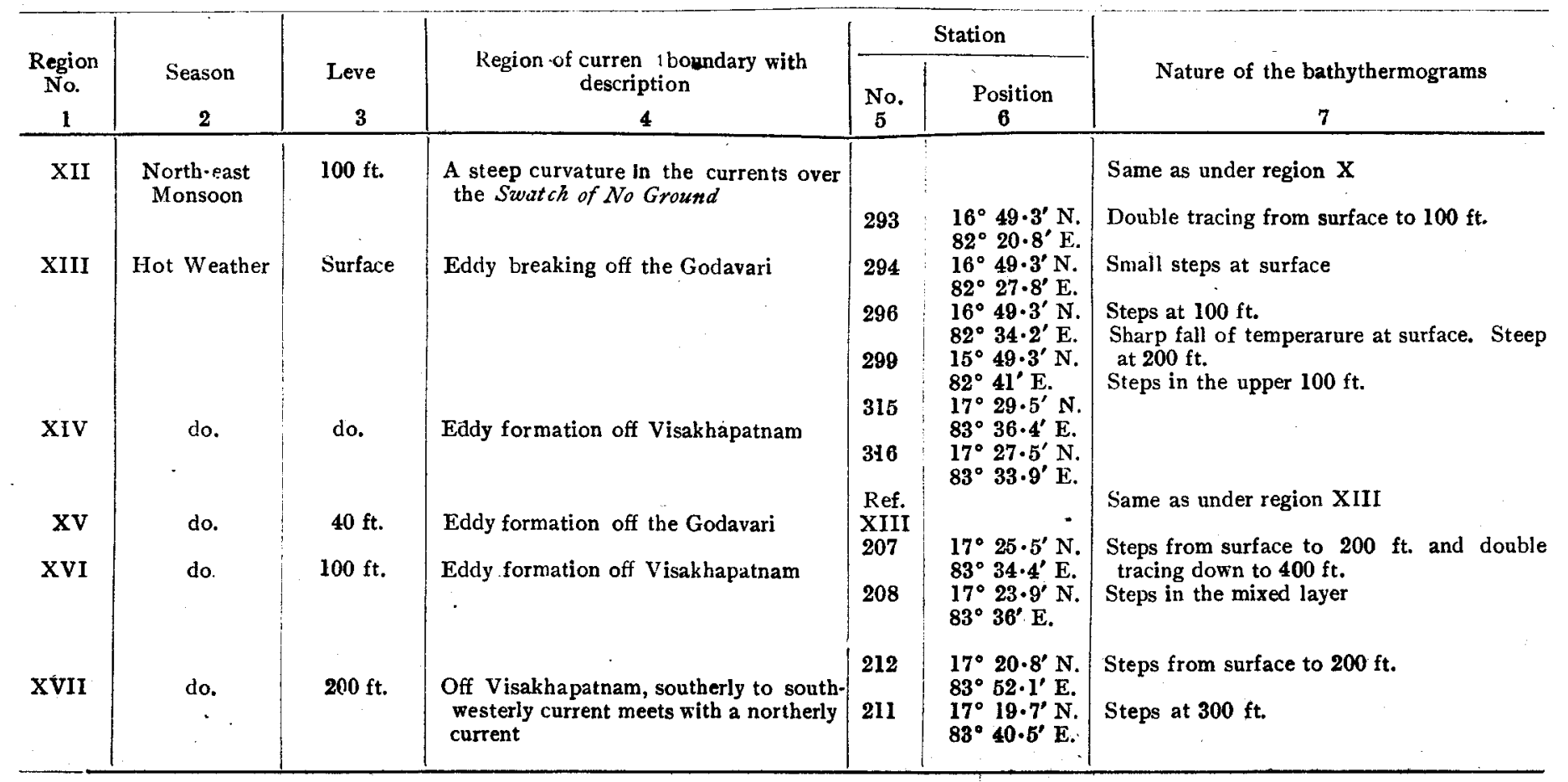


coast. Hence the extent and the duration of the presence of this water on the continental shelf off Visakhapatnam is greater than in the south (i.e., say, off the Godavari). An examination of the isotherms at 100 and 200 feet levels, in a region between north of the Godavari and south of Visakhapatnam, reveals the intensity of the current at these levels. But in the surface waters, even though the strength of the current is not weak, much turbulence appears. : Further.south in this region the isotherms are widely spaced except in the 400 feet level chart (Fig. 20) where the isotherms are nearly uniform in the entire chart.

Thus the current is weak and north-easterly in the south and intense and turbulent in the north off the Godavari upto 200 feet level while at 400 feet the current is nearly uniform in intensity and is northerly upto the Krishna and becomes easterly upto the Godavari and north of the Godavari it turns north-westerly and finally it becomes a north-easterly current.

Current Boundaries.-A current boundary may be defined as a region where two currents from opposite or "nearly opposite directions meet. In such a case, different watermasses with different conservative properties such as salinity or temperature come in juxtaposition. If the vertical distribution of the temperature or salinity is studied in such regions, one will find, often, steps in the respective profiles. This characteristic feature can be traced in bathythermograms also. In Table I, the regions of current boundaries that are noticed at each level have been indicated. Where observations are available in such regions, the bathythermograms have been analysed. The analysis of the bathythermograms has been entered in the last column of Table I. It will be found from this analysis that the bathythermograms either show steps in a layer whose mean depth is round about the depth of the level under consideration, or the bathythermogram shows two different lines separated by about one degree difference in temperature. This is due to the fact that each tracing is made as the instrument is lowered into and heaved up. In the short interval of the downward and upward travel of the instrument the different watermasses give their characteristic temperature to the thermal element of the instrument, thus resulting in two curves side by side. This analysis not only gives a method of exactly locating the current boundaries but also serves as a verification of the validity of the method employed to draw conclusions regarding the possible directions of currents from the thermal field, provided no consideration is taken of the bathythermograms which are showing the expected characteristic. While drawing the isotherms, actually the mean temperatures are taken from such bathythermograms. 
From Table $I$ it is seen that no boundary is exhibited by the bathythermograms in the region I. This is so because the two rotating systems are seen as mainly of thermal origin. It has been already shown in the present investigation (by salinity consideration) that such rotating current system does not exist to any appreciable extent. However at all other regions considered, current boundaries exhibited by the bathythermograms provided a check over the validity of the currents entered. However, further investigation, either by direct measurements or dynamical computations, is highly desirable.

\section{Seasonal Variation}

The temperature of the sea is effected by the processes of heat transfer, viz., the advective processes and the energy transfer. In the surface layers, where the effect of solar radiation is very intense, the processes of energy transfer are of utmost importance. The time and space means of the sea surface temperature and air temperature together with the difference for every month have been worked out by Ramasastry (unpublished). His values have been reproduced in Table II. From this table it is seen that the sea

TABLE II

Comparison of sea surface and air temperatures

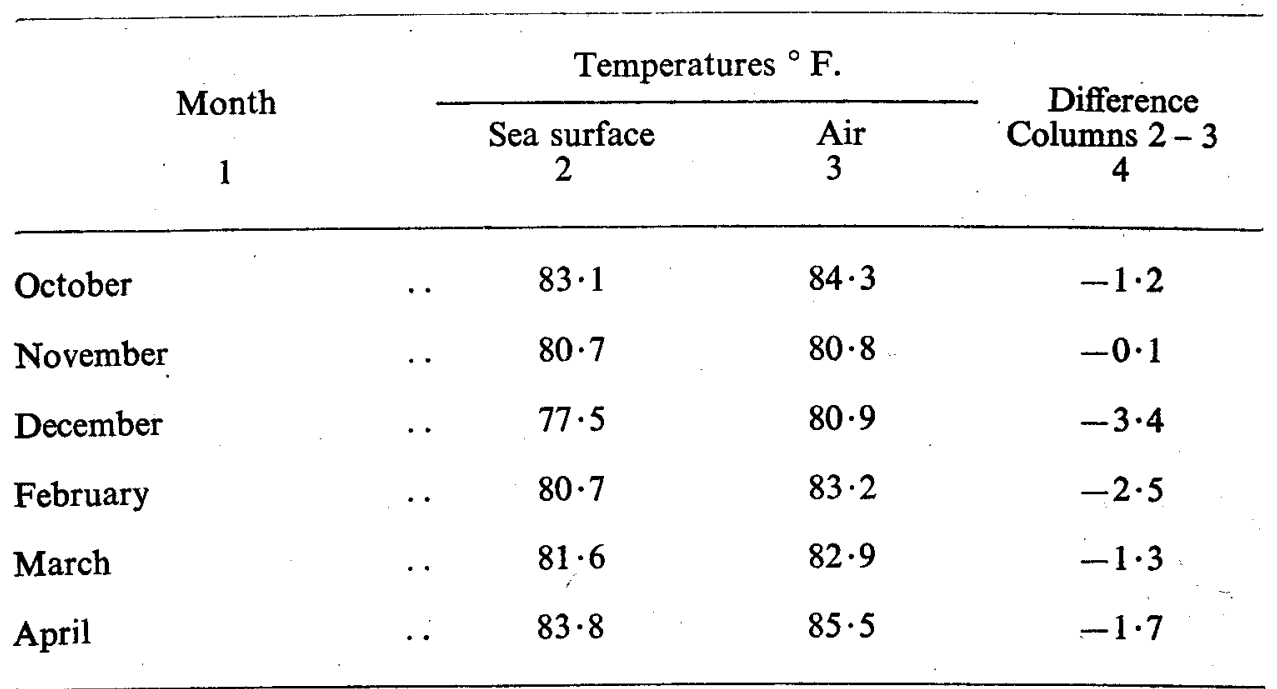

surface is always colder than the air in all the three seasons, the greatest difference being $3.4^{\circ} \mathrm{F}$. in December. This means that heat is always transferred from the atmosphere to the sea, the maximum transfer being in winter. 
But the thermal field shows some peculiarity which reflects the various processes that are responsible for the changes in temperature of the sea. This is well brought out by a level-to-level comparison of the temperature fields in the three seasons under discussion. For this purpose in Table III, the maximum and minimum values of temperature for each level in different seasons have been indicated (from the charts prepared, the temperatures are given in whole ${ }^{\circ} \mathrm{F}$.). Also the range of temperature and the place of occurrence of maximum and minimum temperature zones are given.

As a detailed discussion of the thermal field and the associated currents has been presented in the earlier pages, the seasonal characteristics have been briefly summarised in Table III, on which a discussion is presented here.

Discussion of Table III.-During the Post-Monsoon season sea surface temperature begins to fall gradually reaching a minimum early in the Northeast Monsoon season. The difference between the sea surface and air temperatures becomes reduced towards the end of this season and sinking gains in intensity during the middle of the season. Due to this, the topmost layers are characterised by nearly uniform temperature along the coast, while offshore the temperatures are much less as is indicated by column 5 in Table III. The maximum range of temperature, occurs at 200 feet level. This is because the thermocline develops almost round this depth near the coast as a consequence of sinking, while it is much shallower well off into the Bay, where sinking is not much prominent.

During the North-east Monsoon season, the sea surface temperature shows a minimum as a result of surface cooling by the reduction in the intensity of the solar radiation. The subsurface layers do not cool down and hence a subsurface zone of maximum temperature, as was presented by LaFond and Borreswara Rao (in print), has formed, not only in the east coast of India (to which region they have confined their studies) but also at the head of the Bay. From column 9 in Table III, it is seen that at all levels highest temperatures occur towards the coast at the estuaries of the Ganges and a low temperature just on the submarine canyon. On the boundary of the canyon the presence of vertical instability in the top layers of the sea has been found by Ramasastry (unpublished). Due to this instability uniform temperatures in the top layers must result as a consequence of vertical mixing. But on the contrary the temperature increases with depth indicating the extent of surface cooling due to the advent of winter. The maximum range of temperature is found only in the topmost layer, whereas in the GodavariVisakhapatnam region it is found at 200 feet level as in the previous season. 
TABLE III

Seasonal Characteristics of the Thermal Field

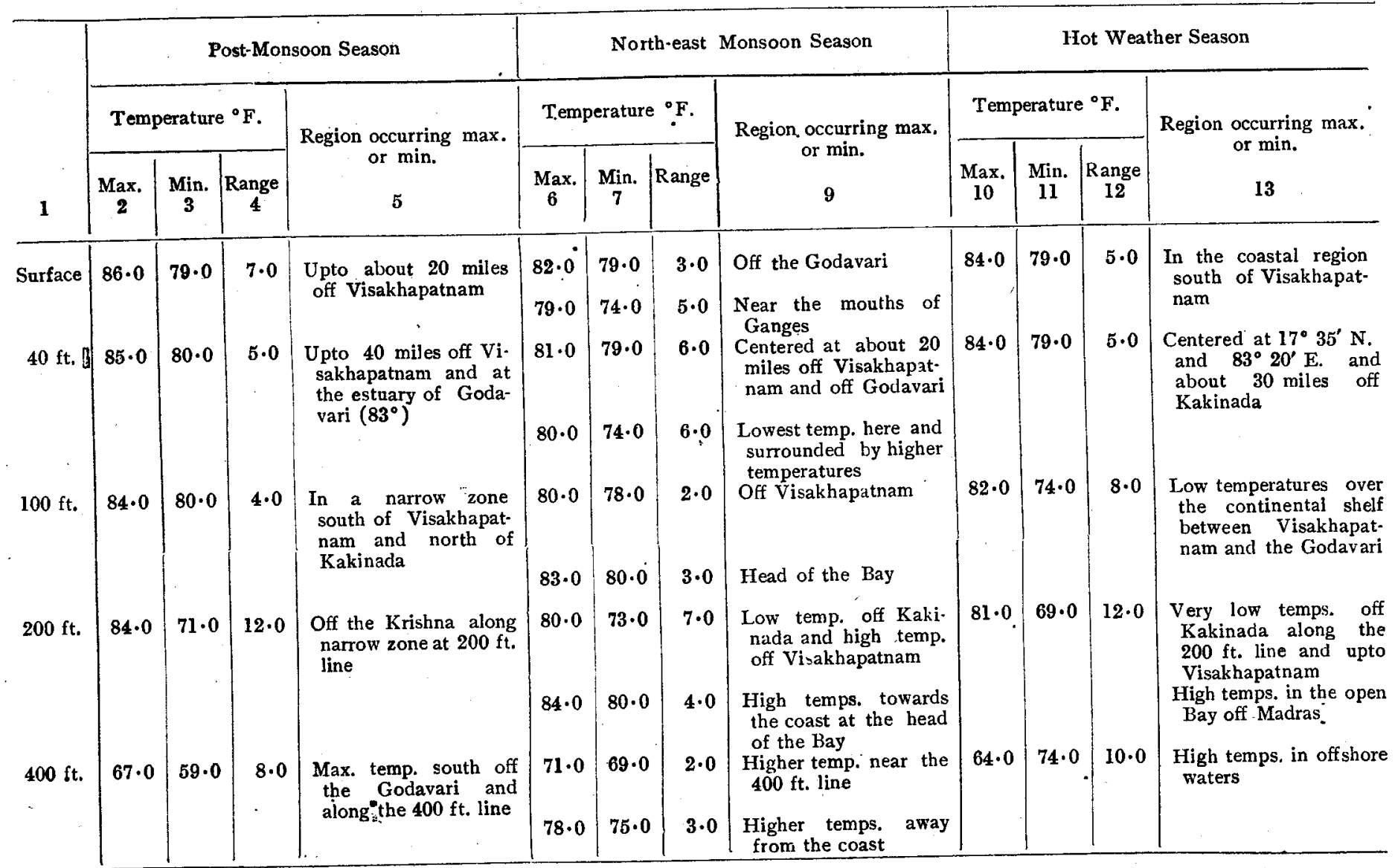


Owing to the increased intensity in the solar radiation towards the end of winter and with the change in the direction of the surface winds, mixing in the top layers is completed by the end of February and the subsurface zone of maximum temperature is completely eliminated. Upwelling starts and gains in intensity during this period, so much so the depth of thermocline will be shallower near the coast than offshore. The conditions will be just the reverse to those in the Post-Monsoon season. This is made clear by comparing columns 5 and 13 in Table III. During this season also, the maximum range of temperature occurs at 200 feet level.

\section{REFERENCES}

1. LaFond, E. C.

. "On upwelling and sinking off the east coast of India," Andhra University Memoirs in Oceanography, Andhra , University, Series No. 49, 1954.

2. and Borreswara Rao, C.

"Vertical temperature structure of the upper layers of the sea off the east of coast of India," Defence Science Journal (in print).

3. Ramasastry, A. A.

"Vertical temperature structure of the sea along the south coast of India," Ibid., October, 1954.

4.

"Vertical temperature structure in the north-western Bay of Bengal and over the Swatch of No Ground." (To be published.)

5.

.. "Vertical temperature gradients in the Bay of Bengal and the Arabian Sea." (To be published.)

6.

. "Diurnal variation of the temperature structure of the sea." (To be published.)

7. Sewell, R. B. S.

.. "Temperature and salinity of surface waters in the Bay of Bengal and Andaman Sea with reference to Laccadive Sea," Memoirs of the Asiatic Society of Bengal, 1929, 9 (5), 207-351.

8. Sverdrup, H. U., Johnson, M. W. Oceans, Their Physics, Chemistry and General Biology, and Fleming, R. $H$. Prentice-Hall, Inc., New York, 1946. 